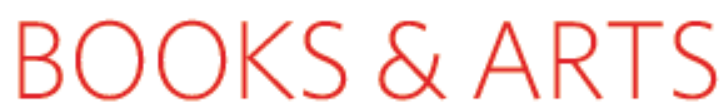

\title{
Scientists on screen
}

\section{Does Hollywood think we're all dangerous megalomaniacs with crazy hair?}

\author{
Mad, Bad and Dangerous: The Scientist and \\ the Cinema \\ by Christopher Frayling \\ Reaktion Books: 2005. 239 pp. £19.95, \$35
}

\section{Adam Rutherford}

Joey: It's like reading a script. Like, "This is a Tyrannosaurus rex, a creature from the Jurassic period.”

Ross: Actually, Joey, it's the Cretaceous period.

Joey: Yeah, but, I can pronounce Jurassic.

Watching Friends, the pre-eminent US sitcom of the 1990s, I once found myself in the embarrassingly geeky position of correcting Joey's gaffe half a second before Ross did. Fortunately, I have few friends myself and this smart-arse moment passed almost unnoticed. Ross is an urban New Yorker, a loving father with a tight network of close friends. He is attractive and socially well adjusted (if a bit wet). He is also a lab-based palaeontologist, a postdoc working in a prominent metropolitan museum.

Ross spends little time writing grants and a lot of time hanging around coffee shops. In this regard, his is a hugely inaccurate portrayal of a working scientist. But at least he doesn't display any of the stereotyped traits associated with scientists in the movies, outlined in the title of Christopher Frayling's new book, Mad, Bad and Dangerous.

Frayling has reviewed in detail the changing role and perception of scientists in more than a hundred years of cinema. His analysis is partly chronological but desperately uneven. Frayling, a cultural commentator with a clear love of cinema, frequently comes across as a fanboy, albeit a rather academic one.

He covers films from the first half of the twentieth century rigorously, detailing lost or forgotten reels with the precision and loving hand of a devoted film historian. But his coverage of the modern era is more sporadic. The rather desultory selection of films he analyses in detail include some that might not figure in a cinéaste's list of classics at all. A detailed deconstruction of Stanley Kubrick's cold-war masterpiece Dr Strangelove is welcome after tracts on many films from the silent era. But to my mind, The Man with Two Brains falls into the category of films, like Blazing Saddles, that are remembered as being funnier than they actually are. It's a clumsy comedy, slapstick

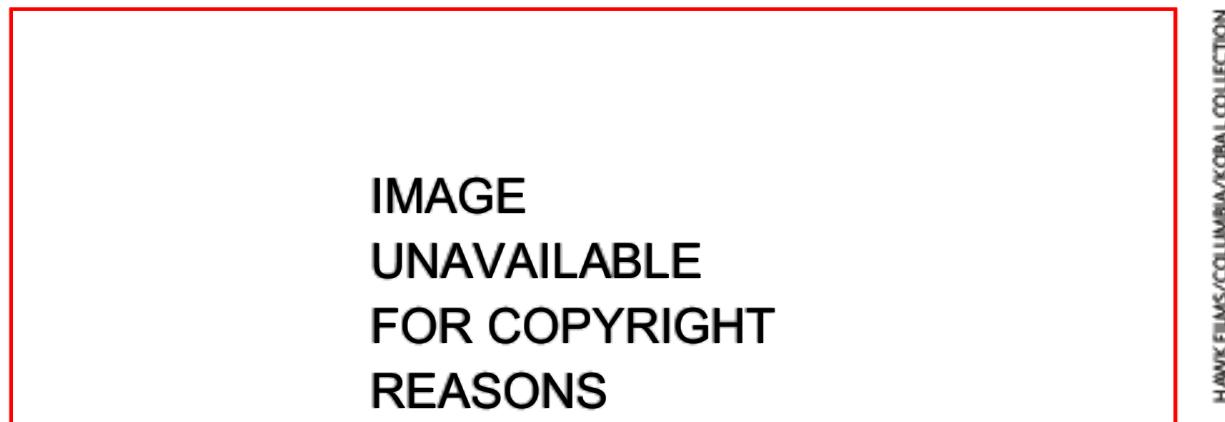

Just a typical scientist?

Dr Strangelove, played by

Peter Sellers, does battle with his uncontrollable arm.

funny at best, and doesn't strictly feature a scientist (Steve Martin's Dr Hfuhruhurr is a brain surgeon), let alone a particularly stereotyped version of one. Its presence in this book seems unwarranted.

Devoting more than a page to mercifully forgotten Australian funny man Yahoo Serious and his frankly dreadful film Young Einstein, while only mentioning in passing the original 1972 version of Solaris (Steven Soderbergh's remake doesn't get a look in), is at best an idiosyncratic decision. And where is The Day After Tomorrow (2004), the mega-budget ecodisaster film that, thanks to some canny marketing, received much coverage in the scientific press, this journal included?

It doesn't bother me that Penelope Ann Miller wears a cocktail dress to do battle with the mutant beast, half reptile, half insect, half human (it's that bad), in updated B-movie The Relic, as Frayling points out in one of the few sections detailing the portrayal of female scientists. She was, after all, at a swanky party when the beast got hungry. I was much more impressed when seeing this as a genetics undergraduate with the (fairly) accurate use of the enzyme reverse transcriptase to explain away the genesis of this wicked chimaera. Maybe Joan Allen's sensitive and passionate stem-cell biologist from Sally Potter's film Yes was too recent to be included.
Frayling has certainly done his homework, and Mad, Bad and Dangerous is bulging with factoids. Did you know that scientists feature as heroes in only $11 \%$ of horror films, but that mad scientists have caused bad things to happen in an eye-popping $31 \%$ ? I found myself scratching my (egg)head at these data, but mostly in bewilderment at their relevance. Sometimes it's not clear whether he's talking about scientists, doctors, psychiatrists or explorers, and frequent references to television programmes obscure the line between the small and big screens.

Several studies exploring the stereotyped image of a scientist come under Frayling's gaze. These are interesting enough, if not wholly surprising. The influence of Hollywood imagery cannot be underestimated. When mentioning Frankenstein, we tend to think of Boris Karloff's flat-headed creature with a bolt in its neck, although this depiction belongs entirely to Universal Pictures and not Mary Shelley. But it seems that Einstein's late career decision not to comb his hair much was just as significant in creating a stereotype that scientists are invariably detached, bespectaded, crazy-haired social misfits.

Frayling's implicit conclusion is that scientists have been portrayed inaccurately throughout the history of cinema, although their dual role as unlikely hero and evil baddy has shifted 
a little over time. Peter Sellers' Dr Strangelove is described as the archetype, certainly without morals, but where's the crazy hair? Do we as cinema-goers (or indeed as scientists) turn to Hollywood for accurate portrayals of scientists? Of course not. Nor should we, any more than we expect accurate portrayals of politicians, pirates, spies, drunks or even penguins in the movies (and that includes the 2005 surprise hit documentary March of the Penguins). Perhaps we should praise Friends for portraying a scientist as someone who is just a little bit normal. Adam Rutherford is aneditor at Nature Publishing Group.

\section{Return to the fortress}

\section{The Science and Fiction of Autism \\ by Laura Schreibman \\ Harvard University Press: 2005. 304 pp. \\ $\$ 27.95, € 17.95, € 25.80$}

\section{Michael Fitzpatrick}

When my son was diagnosed as autistic some ten years ago, a friend's mother - a retired social worker - lent me a battered copy of Bruno Bettelheim's book The Empty Fortress (Free Press, 1967). This was the book that popularized the psychodynamic theory that autism was a result of defective parenting - a notion that caused much distress when children were removed from their 'refrigerator mothers' and 'aloof and obsessive fathers', and subjected to intensive psychotherapy in residential institutions. By the time I read Bettelheim, these theories had long been discredited and his book was of merely historical interest.

In The Science and Fiction of Autism, Laura Schreibman, professor of psychology at the University of California, San Diego, provides a comprehensive account of controversies in the field of autism. She discusses the impact that psychodynamic theories of autism had in the 1960 s and 1970 s despite the lack of scientific evidence supporting either them or the therapies with which they were associated. She recalls that, in the $1980 \mathrm{~s}$, the mother of an autistic child removed Bettelheim's books from the local library and threw them away, and mobilized other parents to do the same when they were replaced. Though I balk at any form of book-burning, parental anger was understandable given the consequences of Bettelheim's theories. As Schreibman acknowledges, the legacy of blaming parents has left a lingering "atmosphere of distrust and suspicion" between some parents and professionals in the sphere of autism.

With more than 30 years of clinical experience, Schreibman brings a valuable historical perspective to her discussion of the controversies surrounding the diagnosis of autism, its causes and its treatments. This is particularly helpful to parents, who may turn in distress and desperation to the latest wonder treatment. From this book they can learn how an earlier generation of parents was drawn, with familiar promises of recovery and cure, down the dead ends of 'holding therapy' or 'facilitated communication'. As Schreibman observes: ${ }^{\alpha}$ One need not be a scientist in order to know how to evaluate information critically; one just needs to be appropriately critical." Her opening chapter provides a readily accessible guide on critical evaluation that could save parents - and their children - from much grief.

Schreibman's experience is also apparent in her survey of her own sphere of expertise: behavioural treatment programmes. She presents a detailed critique of some of the extravagant claims made on behalf of Ivar Lovaas' and dietary therapies). Working in alliance with rogue scientists and doctors, groups of parents have linked up through the Internet to pursue strident campaigns promoting interventions of unproven efficacy and uncertain safety. Like earlier campaigns based on miracle cures, these are likely to prove damaging to the families of autistic children, but on a wider scale. If these campaigns undermine child immunization programmes, other families too will be damaged - in Britain we have already seen outbreaks of measles and cases of measles encephalitis in unvaccinated children.

One largely unrecognized aspect of Bettelheim's legacy is that professionals in the world of autism, burdened by the guilt of the past, tend to be reticent in confronting the junk science that underlies much contemporary parent activism. Although today's activist parents never suffered from psychodynamic theories as an earlier generation did, they do not hesitate to cite Bettelheim to legitimize their sense of victimhood and their rage against the medical

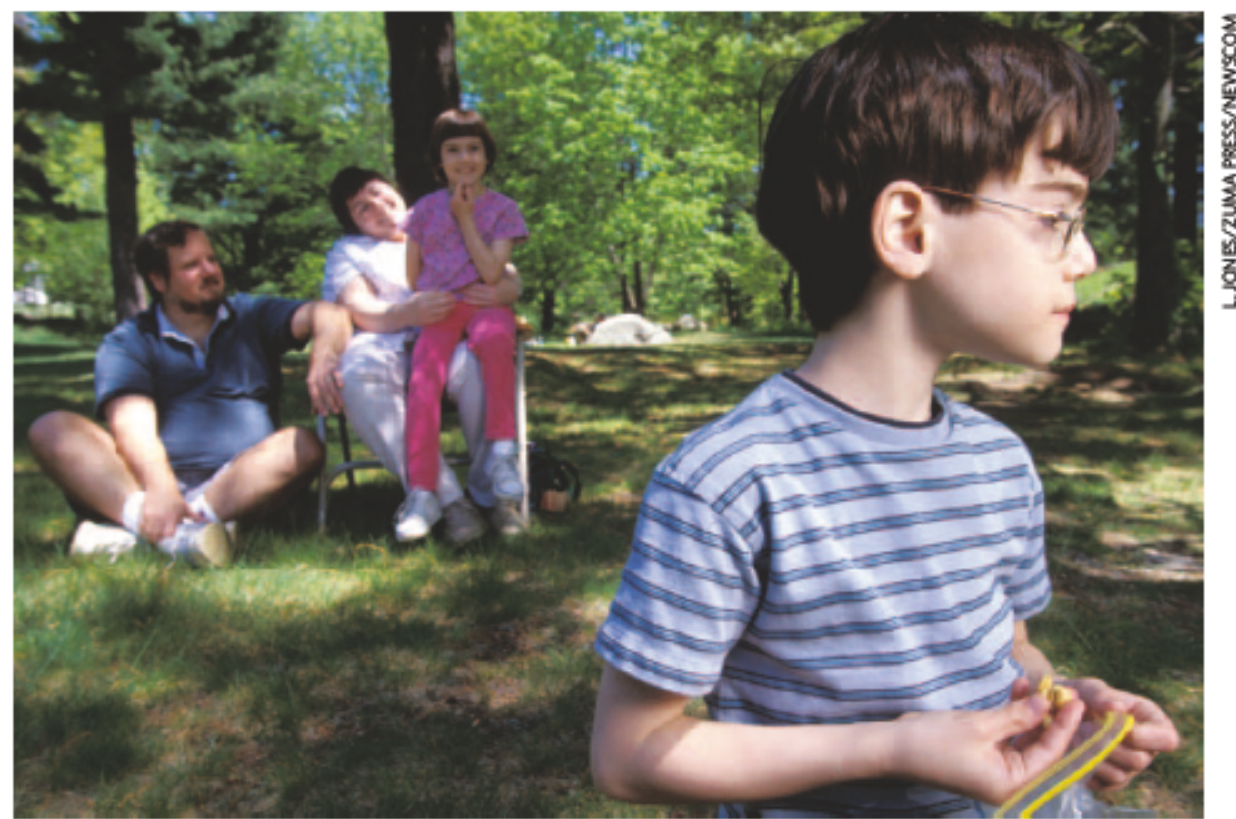

Child prodigy Matt Savage uses jazz to escape the isolating effects of autism. But how do parents cope?

'applied behavioural analysis', while noting that, for some children, early behavioural interventions have shown impressive results. Her approach is refreshingly undogmatic and pragmatic, emphasizing the importance of applying theory flexibly in relation to the particular needs and circumstances of the child. She is impatient at polemic over inclusion, dismissing the controversy over whether autistic children should be taught at home or at school as "another meaningless debate", insisting that what matters is how they are taught, not where.

In her concern to mend fences on the troubled boundary between parents and professionals, Schreibman perhaps underestimates the challenge arising from the current wave of parent activism around "unorthodox" biomedical theories (such as links between autism and vaccines) and treatments (such as chelation establishment. The result is that activist groups, which are unrepresentative of parents in general and not accountable to them, and which often have links with commercial interests that provide expensive investigations and treatments, have enjoyed growing influence without facing a concerted challenge from experts in the relevant disciplines. If Schreibman's book encourages both parents and professionals to adopt a more critical approach towards such campaigns, this will protect families from further "crushed hopes, ineffective treatments and false starts". It will also help to restore appropriate boundaries between parents and professionals. It may therefore make an important contribution to the welfare of children in general, and those with autism in particular. Michael Fitzpatrick is a GP in Londonand author of MMR and Autism: What Parents Need to Know. 